\title{
The school that students could enjoy
}

\author{
Judit Torgyik
}

\begin{abstract}
This study presents a research based on semi-structured interviews among Hungarian students who attended different schools and are aged 7-18, in order to get to know what they think about the concept of a good school. The analysis contains the link with the pedagogue, relationships among the students, way of teaching, teaching materials and the appropriate classroom environment. According to the outcome, the desirable school pays attention to the basic human needs and is founded on the holistic approach.
\end{abstract}

Keywords: students' aspects; good school; teacher's role; relationships among students; classroom atmosphere

Subject-Affiliation in New CEEOL: Social Sciences - Education - School Education

DOI: 10.36007/eruedu.2021.4.83-92

The students are supposed to be the participants of education for several years and gain a lot of personal experience that could be applied in the school innovations, as well as during the development of the institutional quality to a given extent. It is a new international trend that their opinions and ideas are asked. Surveys are completed in co-operation with students in several countries to apply their ideas and opinions to establish an appropriate school life.

Such survey was completed in Finland, where twelve-year-old pupils were asked what they would improve in their school, class, city and country. (Virta and Virta, 2015) The most common points about their school were meal and the reformation of internal and external environment. An other survey in Estonia has compared the students' satisfaction with the well-being at school. (Dagmar, Soo, Liis-Marii, 2019) A good school in Scandinavian countries is supposed to be a place where students feel well and that's why their opinions are monitored regularly.

There are just a few pedagogic surveys available on this field in Hungary. We can mention the works of Sándor Klein (2002) who was investigating a similar question and asked the students about their satisfaction with and the feelings about their schools during his teaching at the University of Szeged. I wanted to join the studies focusing on the students' voices because my purpose was to learn what the points of public education students are to describe the good school. To accomplish this primary and secondary school students were interviewed in the frame of an empirical survey. The randomly chosen participants were 7-18 years of age, living in Budapest or big cities and villages of Hungary. Each student attended to different schools all over Hungary and 40 half-structured interviews were completed during the school year 2018/19. The interviews were made by the students of 
Kodolányi János University in the frame of the lesson of research methodology. I have analysed these interviews and evaluated the findings from the points of relationships within the school, relationship between the teacher and the student, relationships among students, content and way of education, as well as institutional environment.

\section{Human relationships and the requirements for teachers}

A good school is featured by positive interpersonal relationships, especially an accepting and safety providing teacher - student relationship. Both psychological and educational scientific surveys prove that the personality of a teacher has a relevant influence on the students' emotional well-being, performance, attitude to learning and subject. (Klein, 2002, Rogers, 1986, Falus, 2003) A good teaching atmosphere facilitates the development of personality. If the students feel an accepting atmosphere based on mutual respect during the process of teaching, they are resistant to the influences of stress, can better manage the challenges and cope with the different tasks even if they have some learning difficulties. The resilience is supposed to be connected to well-being at school, as well as the extent of acceptance. (Rayman, Varga, 2015) The safe and supporting teacher - student relationship is especially important for students of minorities, being somehow disabled or endangered by elimination but it is important for the other students as well. It can be observed that the feeling of a positive school atmosphere maintains the motivation to learn during the years, as well as decreases the risk of drop-out. (Batini, Marco, Ermelinda, 2019) A pleasant atmosphere supports the well-being at school but its lack can lead to mental problems, stress and pressure. (Slee, Skzypiec, 2016)

Students' responses show that the good school means mainly the good teacher and the solidarity of the class for them. The quality of human relationships determines the spirit and the atmosphere of an institution. The teacher's personality contributes to the satisfaction with school and influences the attitude to schools very much. The more imaginative way of thinking and the series of more creative ideas are much more common among the responding pupils of young age than among the older ones and the secondary school students. Their free and more flexible way of thinking resulted in stranger and more original ideas. The good human relationships provide a kind of defence against the emotional problems and the difficulties of life. The interviewed students expect the empathy, the understanding, the patience, the care, the support, the fair management, and the reasonable motivation from the teacher's side. Furthermore, they expect the encouragement and motivation of learning and the way and speed of teaching meeting the skills, abilities and rate of development of the class. Children love humour, kindness and appreciate the mutual respect and reflect on their mates' misbehaviour to other children or the teachers. The elder ones more often emphasized the teachers' professionalism, love for his/her job and the importance of the clear explanation. The features of a good teacher identified in this study are similar to the ones described in Iván Falus's 
previous works. (Falus, 2003) Many students are of the opinion that it depends on the teacher if they like a subject. The enthusiasm, the professionalism of the teacher and the extent of fascination can facilitate the love for the subject, as well as the establishment of engagement toward the school or the given field of science.

"The clear task of the good teacher is to motivate, that is... The teaching material can be learnt from textbooks and there are different new developments, and we might have robot teachers in the future, so the only difference is the fact that there is an empathetic person who is able to motivate; it is the most important task, I think." (Interview 8)

"I expect the teacher to see me as a human person, as well as an individual and not just one of the students." (Interview 40.)

"He/she is supposed to know jokes, understand the kid's points, but the lesson shall be enjoyable" (Interview 6.)

"The example of the best teacher is my Italian language teacher; she is a very intelligent lady of her middle age, committed to the language, knows a lot about it, interested in the culture and visited the country several times. She organises trips... interesting and exiting excursions every year. She is very good at grammar, listens to us and tries to teach through her examples. She tells us funny stories." (Interview 20.)

The responses clearly show that the good teacher is child-friendly, cares for the students' whole personality and human needs and pays attention not only to the cognitive development of the children, but to their emotional world as well. They care about the class as a community, as well as the relationships among the children, which they also improve and thus form a basically humanised type of school. The teacher focuses not only on the transfer of the centrally determined teaching material and the schedule but the social relationships, the human factors, and cares for the students' emotional life as well. The interviews proved that the students expect personal communication, a frequent "emotional support", as well as the effective assistance to solve conflicts. A teacher can be an encouraging, hope giving, motivating, supporting and stimulating person. (Maholmas, 2014) It provides an emotional security, relief for them that there is someone who understands their joys, sorrows and desires in the school. The conversation is important to prevent problems but listening to and understanding each other is vital from the point of social skills also. (Cowie et. al, 2004)

"... We can discuss our problems with the teacher, and she understands us... It means that a lesson of complaints - as we call it - would be beneficial. ... it can help the students emotionally. We can understand better what is happening to us every day through discussing our problems and difficulties - I think - because I feel much better if I can tell someone what I am concerned for." (Interview 20)

"A good teacher explains what I cannot understand again and again and does not tell me off saying why I did not pay attention and is helpful and supportive and waits for me if I am working more slowly." (Interview 2)

Although, it was not the purpose of the interviews to assess their teachers, the stu- 
dents made comparison on the basis of their experience undeliberately. We could draw a conclusion from the replies that a teacher can be either a positive model for many of them or a reason of unpleasant feelings, fears and stress. The unfair attitude results negative feelings of students, burdens them psychologically and slowly discourages the student from the subject and ultimatelly from the learning. This was found in the study completed by Hunyady, M. Nádasi, Serfözö (2006) and proved by this recent work as well. This problem can establish communication barriers and objects between the parties. The risk of turning-off from learning and school is especially dangerous since one of the most important purposes of the compulsory education is to establish the life-long learning and facilitate the student to learn later when it is not compulsory for them anymore. Furthermore, it is rather important for society to have as little drop-outs as possible. The pleasant school atmosphere and the good teacher-student relationship are of high importance in the prevention of drop-out.

"The chemistry teacher is .... rather fearful and is rude to everybody but anyway has a good heart, but lots of us fear from his attitude... it is quite common that he approaches to the student unfairly and nobody wants to go to him to be handled unfairly again." (Interview 8)

The interviewed students expect their teachers to be computable, plannable, establish stable framework, as well as to declare the schedule at the beginning of the term and check them according to it instead of using unexpected tests. One of the respondents mentioned as a positive example that all of them have already been realized in his school saving the students from many stress factors, negative feelings and anxiety. Further expectations from teachers were the willingness to improve their professionalism permanently and use the modern IT-technology frequently during the lessons. They think that the ICT-skills and the computer assisted teaching can bring the older and younger generations closer to each other. The knowledge of the internet-based programs got especially important during the pandemic and the appropriate skills improve the students' satisfaction and bring the different generations closer to each other. The teachers being more open to the novelties can understand young people better.

\section{The relationships among students}

Like the good teacher-student relationship and the pleasant atmosphere are vital during the school years, the characteristics of the relationships among students are determining factors of the everyday school life. Hervaine (2015) is of the opinion that the well-being in the school is focusing on the care, the listening to students, the human relationships and the communities. Friendships are established during the school years; the students learn from each other, while their social competencies and interpersonal skills are improving. The individual gets social chances within the frame of school socialization. The students can establish more positive relationships in a pleasant class atmosphere providing a factor of mental hygienic health protection for them. (Meleg, 2005, T. Slee, Skzypiec, 2016) There are 
less absences and illness in a pleasant atmosphere and the community teaches acceptance and how to fit in. The quality of the teacher-student relationship affects the features of interpersonal relationships among students. The qualitative school is supposed to be a network of accepting - inclusive - communities and provides the feeling of belonging and support for all students independently of its individual characters. (Newland et. al., 2019) An accepting class provides joy and well-being for students and the common activities and works are a kind of award for its members. The help and assistance to each other are much more common among the classmates in a positive atmosphere. The friendships ease the effects of school stress and provide a mirror for the developing personality. At this age friendship means the classmates for the students.

"I can hardly wait for the start of the new school year during the summer holiday so as I can meet my friends every day again. That is what I like in school." (Interview 15)

"If somebody gets behind, the teachers are ready to explain it him/her or let him/her stay in the school in the afternoon and we, the students help our fellows to understand the lessons." (Interview 20)

Several respondents mentioned that the acceptance of each other, the kindness, the polite behaviour, the helping attitude towards each other, the positive attitude to learning in the class of a good school were important for them because these can provide a kind of encouragement for them. A good community has the power of maintenance and provides support and connection, as well as the power of belonging to somewhere. It turned out that the students are keen on doing cooperative exercises when they can work in pairs or teams. Some non-required features were also mentioned, such as banding, exclusion, jealousy, and the verbal and physical aggression towards others that do not facilitate the balanced relationships. They are required to keep contacts, play together, have common programs, be friends and help each other in out-of-school time.

"It is important to have fun during and out of the lessons, have common hobbies, we could more often play football, Xbox at the weekends." (Interview 28)

\section{The teaching material and the way of teaching}

It has been a discussion in pedagogy for a long-time what content and subjects should be and to what extent should they be taught by the school. In relation to this question, the overload of students was often mentioned. Most of the respondents think they have too many lessons every day; the ideal school should decrease it to provide a balanced load for them. Many of them complained of being tired.

"We seem to learn more or do the homework than the adults work. We arrive home in the afternoon and start to learn and do the homework. It often lasts till evening....5-6 lessons are supposed to be ideal in primary school so as we can have private life and time for anything out of school." (Interview 12)

"The teaching material is so long that we cannot often complete it." (Interview 36) 
The respondents would like to have less lexical teaching materials but more practical and funnier exercises and skill developments during the teaching process. They agree that an introduction of some new lessons could meet the modern requirements of the 21 st Century and the society of today, as well as their personal interests much better. The psychology, political and social sciences, as well as robotics were mentioned for the subjects they would like to learn. The respondents are of the opinion that a quality school is supposed to be open to the modern ways of teaching, the regular application of info-communication tools and the more frequent usage of spots out of school. It is supposed to provide less facts but much more useful and practical knowledge and skill improvement.

Many of them think that a more frequent out-of-school exploration, interactive museum pedagogy and participation in Zoo lessons, a lot of school excursions, watching movies being in connection to the lessons, theatres, forest schools, playground programs and out-of-school sport can contribute to the love for school. The need to open to out-of-school lessons and spots was mentioned several times. The students emphasized active learning, more frequent participation, action, the importance of experience and positive emotions. The students want to act and prove their skills. And, if it is up to them, they want to have some more extra courses and increase the number of free-to-choose lessons. The out-of-school programs fit in the teaching material very well but make the lessons more interesting and richer, as well as help the students get into the details at the same time. The need to be close to nature was mentioned from different points of view; one of them was the nursing of plants, the observation of their growing, gardening, while the other was having breaks in a pleasant environment or the destination of excursions.

"We might go into nature to observe it. The quick tests have no sense, anyway. The purpose of a test in a language lesson would not be to check if we had learnt the words but to choose a given topic and have a conversation about it. I love those lessons when the interactive board is used because it helps to remember the information, I believe." (Interview 28)

"It should provide such experience for the city kids, they have not ever had. Well, it would be a great idea, if we visit a village during the course to milk a cow and feel the atmosphere of the village life. A horse-riding and archery would be great also." (Interview 18)

Young primary school pupils are keen on playing and listening to tales during their lessons, while the older ones would like to get help and points to establish their future, learn the different professions and choose the best one for them. The students' responses show that play and the playful way of teaching should be more frequent in the schools and part of all subjects.

"I would like to learn more about the present and the future" (Interview 15)

"We should learn more about ourselves and how man is "operating". I would like to learn psychology and about the current political system." (Interview 17)

The respondents are of the opinion that a good school is based on conversation, focuses on the future and its modern way of thinking maintains the desire for learning and curiosity. It should rather apply the interactivity and base the ways of teaching on the students' questions, needs for communication, discussions and 
actions.

"If the number of students is not too high, we can sit in a circle in the class; it would be much-much better." (Interview 28)

"we could make a circle or smaller teams easily and quickly according to the teacher's points and the requirements of the task" (Interview 18)

An other important point of the respondents was the increased need for creativity, that is, they would like to have more of such types of lessons and tasks where they can prove their creativity and imagination (e.g. cooking, craftworks, arts, creative writing). It was mentioned several times that they wanted to get practical skills that can be used in everyday life, as well as more help to solve the everyday problems (such as official things, understand the world of authorities, labour knowledge, gardening). Furthermore, they want to gain experience and try out new activities.

"It would be beneficial to learn how to use cash, pay a check, live without wasting money, it is also very important not to collect everything in plastic, not to burden the Earth and not to waste. We would like to listen to their experience and watch how they could manage to build up a house, arrange a garden and how they could reach the different levels of their lives." (Interview 20)

The compulsory readings were also criticised: "I do not really like the old ones for many of them seem to be a mess, I would like to read modern and clearer books, even Hungarian folk-tales, but anything, which is newer and having more sense from my point of view." (Interview 2)

This quotation above shows clearly that the language of teenagers and the language of compulsory readings are completely different and the latter one is completely unclear for many students. This student has clearly expressed the need for changes in this field.

\section{The physical environment of school}

Positive human factors are completed with appropriate objectives and infrastructural conditions in a quality school. The building, the facility, the internal and external environment of a school can influence its evaluation, as well as the well-being of students. The beautiful and harmonic environment generates positive feelings (Dagmar, Soo, Liis-Marii, 2019), as well as its attractive features can contribute to the appropriate conditions of learning and teaching.

It was a general requirement for the institution to be spacy, light and sun-lit, as well as to have pleasant and happy facility to generate harmonic impression and positive feelings. The students expect colourful, friendly and happy external and internal environment. The schools shall have enough external and internal rooms meeting the students' number and age. The facilities, the furniture are comfortable and ergonomically designed. The classrooms are decorated by the teachers and the students and the students' ideas are appreciated. A green area of reasonable size is provided and they care for the grass, the trees and the flowers in the school yard and participation in gardening. The vicinity of nature, the flowers and the gar- 
den were of high importance in the respondents' replies. The need for gardening and learning how to grow different plants within the frame of the lessons was mentioned several times. Many of them mentioned the need for cleanness, order, hygiene, as well as the care for nature. Although the young pupils mentioned the playing and the school playground because it is very important for their age, the older ones require the different playing activities in the school as well. More room should be provided for moving and sport activities, but even for quiet relaxation, too.

"I would like to build a real playground with swing and jungle gym in the school-yard and plant a lot of trees and flowers around, and, of course, a small vegetable garden. We could water it." (Interview 34)

"Table football would be great!" We miss it really, and I have heard that other schools have slot machine to sell Túró Rudi (a kind of Hungarian sweet curd cheese rod with chocolate cover). Of course, they are not vital, but can make the breaks better. Perhaps, some armchairs or puffs can be placed in the corridors." (Interview 13)

I think, it is important from the point of the environment to have trees and green plants where we can have our lunch in a beautiful environment during lunch break. It makes us more willing to go to the next lesson. It is really important because we do not really have the chance to enjoy the beauty of plants in the city." (Interview 20)

"Silence, fresh air, a big room and a calm conversation in small groups are very pleasant during breaks." I always get fresh outside." (Interview 39)

A smaller group of respondents described the features of the school and its environment they do not want and what they want to avoid: "it shall not be ruined!" "it is not the desert we want to see" "we need grass and not an empty place", "no concrete is needed" - said many of them referring to the fact that an empty, bald place is not suitable for an institution that transfers science and culture.

"It shall be designed but not in such a way as in 1900s when the walls were white and the teacher was in height and everything was sad, it shall be homelike." (Interview 6)

They imagine a nice place where they can enjoy themselves, be happy and express their emotions instead of a sad and old-fashioned school building and concrete-covered school yard. The students are of the opinion that "hot chocolate machine", "movie", "slide", "football ground", "volleyball ground", "bicycle course", "swing", "scooter course", "swimming pool", "well equipped gym with training facilities" shall be found in an ideal school. The students, mainly the boys, mentioned sports in connection to school. They want to move, play football, basketball and handball during the breaks. Meanwhile, many of them mentioned meals, and the improvement of its quality, as well as a good canteen and buffet. The yard means the place of free movement, where they can forget about their duties, relax and feel the freedom for the respondents, and it is important for them to be outside and spend their breaks in a nice and shadowy environment. Younger pupils completed their wishes with playful elements and creative ideas: "The bell is fairly loud. It has a melody like in a tale and can be changed to be completely different on each floor." (Interview 35) 
Similarly to human relationships, many of them compared the school environment of their actual school and the ideal one. The general hygienic condition of toilets and basins, as well as the general lack of security were mentioned in this context. Many of them think that the ideal and real school atmosphere are not often similar. "well, the toilets, uhm... Many students go to the toilet in the breaks, and we need much more. And there are no locks on the doors and toilet paper and soap are missing." (Interview 6)

A quality school has a clean and arranged environment and its specific features help to maintain a healthy spirit and body. The environmental factors and the physical conditions influence the behaviour, the way of thinking about and the attitude towards school and provide a basic condition for learning and teaching. The cleanness of the public areas and hygiene are especially important at the time of a pandemic.

To sum up, the interviewed students replied honestly and expressed their requirements and their feelings and wishes about school. We may say on the basis of the study that a good school is basically humane, children friendly, based on the consideration and satisfaction of the basic human needs during the teaching, as well as transfers the required knowledge and improves the skills from the students' points. It means that it belongs basically to the humanistic pedagogy and psychology that observes the whole human being and the child's internal needs and uses it as a basis for planning, organising and completing the teaching processes. The good school observes the students' body, spiritual and social development, their human relationships and their personality as a whole. Student satisfaction is provided by the holistic approach when the human being, i.e the student, together with his/her cognitive, emotional and social features as a complete complexity, is the focal point and has a positive aspect. The respondents are of the opinion that a school described by them is a kind of institution that in many apsects is similar to the world of reform pedagogical schools and applies those values that can be applied in the frame of a traditional school. It provides a chance for child activity, action, creativity, experience and is open to the out-of-school teaching activities, improves the human relationships and emotions, as well as reaches the emotions. Its positive attitude establishes bonds to learning and facilitates the establishment of life-long learning.

\section{Literature}

Batini, Frederico, Marco, Bartolucci, Ermelinda, De Carlo (2019): I Feel Good at School! Reducing School Discomfort Levels through Integrated Interventions, Athens Journal of Education, 3. 209-221.p.

Cowie, Helen et. al. (2004): Emotional Health and Well-being. A Practical Guide for Schools. London: Paul Chapman Publishing.

Dagmar, Kutsar, Soo, Kadri, Liis-Marii, Mandel, (2019): Schools for Well-being? Critical Discussions with Schoolchildren, International Journal of Emotional Education, 1. 49-66.p.

Falus Iván (2003): A pedagógus In: Falus Iván (szerk.): Didaktika elméleti alapok a tanítás 
tanulásához. Budapest: Nemzeti Tankönyvkiadó, 57-77.p.

Hervainé Szabó Gyöngyvér (2015): A jól-léti közpolitika a 21. században. Székesfehérvár: KJF.

Hunyady Györgyné, M. Nádasi Mária, Serföző Mónika (2006): „Fekete pedagógia”, Argumentum, h.n.

Klein Sándor (2002): Gyermekközpontú iskola. Budapest: Edge 2000.

Mahomas Valerie (2014): Fostering Resilience and Well-being in Children and Families in Poverty, Oxford: Oxford University Press.

Meleg Csilla (2005): Egészségtámogató iskolai környezet, Új Pedagógiai Szemle, 11. 5870. p.

Newland, A. Lisa (et.al.) (2019): School Climate, Emotions and Relationships: Children's Experiences of Well-Being in the Midwest US. Internationl Journal of Emotional Education, 1. 67-83. p.

Rayman Júlia, Varga Aranka (2015): Reziliencia és inklúzió. Romológia, 10. 9-28.p.

Rogers, Carl (1989): A tanulás szabadsága a 80-as években. Szeged: Juhász Gyula Tanárképző Főiskola.

T. Slee, Philip, Skrzypiec, Grace (2016): Well-being, Positive Peer Relations and Bullying in School Settings. Springer.

Virta, Arja, Virta, Marjaana (2015): What to Change? - How to Have Influence? Children's Ideas about Exercising Power and Participating. Journal of Social Science Education, 2. 81-91.p. 